\title{
DEMOGRAFSKI PROCESI U HRVATSKOJ I U ZAPADNOEUROPSKIM ZEMLJAMA - RAZLIKE, SLIČNOSTI I SPECIFIČNOSTI
}

Pri usporedbi demografskih procesa i promjena u zapadnoeuropskim zemljama i u Hrvatskoj često se u nas površno tvrdi da se radi o „identičnim procesima." Međutim, demografsko-statistička analitička usporedba pojedinih agregatnih i parcijalnih demografskih procesa $u$ navedenim zemljama i u Hrvatskoj pokazuje da o identičnim procesima možemo govoriti samo kada je u pitanju dugoročni smjer promjene tih procesa, kao što je primjerice proces prirodne promjene stanovništva koji obilježava smanjivanje stopa nataliteta/ fertiliteta i proces starenja stanovništva koji obilježava porast staračkog stanovništva u ukupnom stanovništvu. Kod usporedbe mnogih drugih agregatnih i parcijalnih demografskih procesa u zapadnoeuropskim zemljama i u Hrvatskoj, napose kada je u pitanju srednjoročna i kratkoročna promjena, analiza pokazuje da se ne radi o identičnim procesima ni prema smjeru promjene, ni prema veličini, ni prema intenzitetu, ni prema strukturi promjene određenog demografskog procesa. U ovom ćemo radu nastojati te konstatacije potkrijepiti relevantnim podacima i pokazateljima za Hrvatsku i izabrane zapadnoeuropske zemlje.

Ključne riječi: demografska bilanca; sastavnice demografske bilance; sastavnice prirodne promjene; sastavnice migracijske promjene; ukupna depopulacija; prirodna depopulacija.

\section{UVOD}

Prilikom općih konstatacija o demografskim tendencijama, procesima i promjenama u Hrvatskoj tijekom posljednjih pedeset godina, često se površno i netočno tvrdi da se u nas odvijaju identični demografski procesi i promjene kao i u razvijenim europskim zemljama. Razmatrat ćemo primarno zemlje zapadne i sjeverozapadne Europe te neke mediteranske zemlje (dalje u tekstu - zapadnoeuropske zemlje), koje su pretežno članice Europske unije-28. Tu ubrajamo 18 zemalja. ${ }^{1}$ Pri tome valja imati na umu da je u navedenim zemljama završio

\footnotetext{
Od 18 zemalja njih 16 su članice EU-28. To su Austrija, Belgija, Danska, Finska, Francuska, Njemačka,
} 
proces demografske tranzicije i da se one, kao i Hrvatska, nalaze u posttranzicijskoj etapi razvoja stanovništva. Spomenute opće konstatacije o demografskim tendencijama, procesima i promjenama u zapadnoeuropskim zemljama i u Hrvatskoj odnose se prvenstveno na one demografske tendencije, procese i promjene koje su u tim zemljama zabilježene u ranijem razdoblju (prije 1965. godine) i koje se odnose na etapu demografske tranzicije i njezine podetape, napose na kasnu tranzicijsku podetapu koja je neposredno prethodila etapi demografske posttranzicije.

U razmatranju o postojećim razlikama i sličnostima u demografskim procesima i promjenama u navedenim zapadnoeuropskim zemljama, s jedne strane, i u Hrvatskoj, s druge strane, poći ćemo od razmatranja koja se temelje na kriteriju razine ekonomskog razvoja. Tako članice Europske unije (dalje - članice EU) obuhvaćaju, grosso modo, dvije grupe zemalja. Prou grupu čine u bilješci br. 1 navedene zapadnoeuropske zemlje, a drugu slabije razvijene europske zemlje, tzv. zemlje $s$ gospodarstvom $u$ tranziciji (uglavnom istočnoeuropske, bivše socijalističke zemlje), o kojima će biti govora drugom prilikom. ${ }^{2}$

U ovom ćemo se radu zadržati na utvrđivanju značajki koje proizlaze iz usporedbe demografskih tendencija, procesa i promjena u navedenim zapadnoeuropskim zemljama s demografskim tendencijama, procesima i promjenama u Hrvatskoj, s obzirom na činjenicu da se često ističe, kako smo već napomenuli, da su ti procesi u navedenim zemljama i u Hrvatskoj identični. Pri tome imamo u vidu najnovije podatke i pokazatelje Eurostata o promjenama koje su u demografskim podacima i pokazateljima zabilježene $u$ jednogodišnjem razdoblju između 1.1.2012. i 1.1.2013., odnosno u 2012. godini, a koje obuhvaćaju većinom zemlje članice EU-28. ${ }^{3}$ Usporedba relevantnih demografsko-statističkih podataka i reprezentativnih demografskih pokazatelja indicira da ti procesi i promjene u navedenim zemljama i u Hrvatskoj nisu identični, odnosno da se ne podudaraju ni vremenski ni prema karakteristikama ukupne strukture i promjena u strukturi tzv. demografske bilance („bilance demografskog knjigovodstva").

Irska, Italija, Luksemburg, Nizozemska, Portugal, Španjolska, Švedska, Velika Britanija, Slovenija i Hrvatska te dvije zemlje koje nisu članice EU - Norveška i Švicarska. (Hrvatska je 2013. postala članicom EU).

2 U tu grupu zemalja ulazi slijedećih 12 zemalja članica EU-28: Bugarska, Cipar, Češka, Estonija, Grčka, Letonija, Litva, Mađarska, Malta, Poljska, Rumunjska, Slovačka. tion 505.7 milion at 1 January 2013; zatim, EU Employment and Social Situation, Quarterly Review, March 2013, Special Supplement on Demographic Trends 


\section{TENDENCIJE I KARAKTERISTIKE DEMOGRAFSKIH PROMJENA U HRVATSKOJ I U ZAPADNOEUROPSKIM ZEMLJAMA}

Činjenica je da se glavni demografski procesi, a to su procesi depopulacije i procesi starenja stanovništva, i to u dugoročnom razdoblju i u svojoj prosječnoj tendenciji, podudaraju u navedenim zapadnoeuropskim zemljama i u Hrvatskoj u smislu promjene njihova smjera. To se dakle prvenstveno odnosi na smjer ili, preciznije rečeno, na predznak tih promjena. Naime, ti se procesi i promjene $\mathrm{u}$ zapadnoeuropskim zemljama već gotovo šest desetljeća (1955. - 2015.), gledani u svojoj ukupnosti, kvantitativno izražavaju kroz usporavanje, znači kroz postupno smanjivanje stope porasta ukupnog broja stanovnika, koja se polagano tendira prema nultoj ili negativnoj razini stope promjene ukupnog broja stanovnika.

U Hrvatskoj proces promjene, odnosno smanjivanja stope porasta ukupnog stanovništva $\mathrm{u}$ navedenom polustoljetnom razdoblju nije ravnomjeran i $\mathrm{u}$ velikoj se mjeri podudara s dinamikom opadanja stope nataliteta/fertiliteta kao bitne dinamičke komponente prirodne promjene stanovništva (prirodnog prirasta ili smanjenja). Stoga iz analitičkih razloga taj proces u Hrvatskoj valja raščlaniti u dva podrazdoblja: prvo podrazdoblje, 1955. - 1990. godine, te drugo podrazdoblje, 1990. - 2015. godine. U prvom podrazdoblju dolazi u Hrvatskoj do izražaja, slično kao i u navedenim zapadnoeuropskim zemljama, usporavanje, odnosno smanjivanje stope porasta ukupnog broja stanovnika. Tako je npr. prosječna godišnja stopa porasta ukupnog stanovništva Hrvatske koja je u međupopisnom razdoblju 1948. - 1953. godine iznosila 0,82\%, u razdoblju 1981. - 1991. godine prepolovljena, smanjena je na $0,43 \%$. U drugom podrazdoblju (1990. - 2015.) situacija se znatno mijenja i kod Hrvatske se više ni približno ne podudara $s$ tendencijom istovremeno izraženom $u$ navedenim zapadnoeuropskim zemljama. Naime, u Hrvatskoj u podrazdoblju nakon 1990. godine stopa promjene ukupnog broja stanovnika ne samo da pokazuje "tendenciju prema" daljnjem usporavanju svog porasta prema nultoj ili negativnoj stopi već dolazi do izražaja činjenica da se $u$ tom podrazdoblju u Hrvatskoj stvarno dogodilo, stvarno je evidentirano smanjivanje ukupnog broja stanovnika i stopa promjene ukupnog broja stanovnika dobila je negativan predznak. Nastupio je proces koji nazivamo ukupna depopulacija. Popisni podaci ${ }^{4}$ pokazuju da se $u$ oba posljednja međupopisna razdoblja nakon 1990. godine, u razdoblju 1991. - 2001. i u razdoblju 2001. - 2011., ukupni broj stanovnika Hrvatske brojčano smanjio (s 4.784 tisuće u 1991. godini na 4.437 tisuća u 2001. i dalje, na 4.285 tisuća u 2011. godini).

\footnotetext{
Izvor podataka Statistički ljetopis Hrvatske 2005. i Izvješće o popisu stanovništva 2011., Državni zavod za statistiku Republike Hrvatske.
} 
Prema tome, podaci jasno pokazuju da se radi o procesu ukupne depopulacije koji označava smanjivanje ukupnog broja stanovnika i koji je nakon 2011. godine u Hrvatskoj i nadalje u tijeku. Sukladno tome, stopa promjene ukupnog broja stanovnika u oba navedena međupopisna razdoblja ima, kako pokazuju podaci, negativan predznak, a postojeće projekcije izračunate za Hrvatsku, uz pretpostavku ostalih nepromijenjenih čimbenika, predviđaju nastavak toga procesa do 2060. godine. Ako se u međuvremenu ne poduzmu sustavne mjere adekvatne prije svega eksplicitne pronatalitetne populacijske politike, ne zanemarujući pri tome odgovarajuću migracijsku politiku kao sastavnicu ukupne populacijske i razvojne politike, taj će se proces u Hrvatskoj nastaviti zasigurno do kraja stoljeća. To pokazuju i najnovije dugoročne projekcije Populacijskog odjela UN-a koje predviđaju (u srednjoj varijanti) da će se ukupni broj stanovnika Hrvatske u 2100. godini smanjiti na razinu od 2.600 tisuća. $^{5}$

Vrijedno je nadalje naglasiti da se podudaranje tendencije određenih demografskih procesa i promjena u navedenim zapadnoeuropskim zemljama i u Hrvatskoj, u smislu identičnog smjera tih promjena, sukladno postojećim demografskim zakonitostima inercije u promjeni dobne strukture stanovništva, izražavaju i kroz promjene sastavnica demografske bilance (natalitet, mortalitet, imigracija, emigracija), koje su istovremeno bitni čimbenici i odrednice promjene ukupnog broja stanovnika. U tom kontekstu izražena je prije svega tendencija smanjivanja nataliteta/fertiliteta, odnosno smanjivanja ukupnog broja živorođene djece, što onda logično rezultira smanjivanjem adekvatnih stopa: opća stopa nataliteta, stopa ukupnog (općeg) fertiliteta, totalna (reprodukcijska) stopa fertiliteta, specifične stope fertiliteta prema dobi, spolu, bračnom stanju i drugim obilježjima, standardizirane stope, bruto i neto stope reprodukcije itd. Takav proces prirodne promjene, odnosno prirodnog kretanja stanovništva, imanentan je zemljama koje se nalaze u posttranzicijskoj etapi razvoja stanovništva, među kojima se, kako vidimo, nalazi i Hrvatska.

Treba naglasiti da je u Hrvatskoj, za razliku od navedenih zapadnoeuropskih zemalja, proces smanjivanja nataliteta/fertiliteta u drugom spomenutom podrazdoblju, tj. nakon 1990. godine, izrazito ubrzan. U ukupnom 25-godišnjem razdoblju nakon 1990. godine sve do danas (2015. godine), smanjivanje nataliteta/fertiliteta u Hrvatskoj uvjetuje demografsku promjenu kojoj temeljni sadržaj čini prirodno smanjenje stanovništva, prirodna depopulacija, koju u području analitičkih demografskih pokazatelja reprezentira primarno negativna stopa prirodnog „prirasta“ stanovništva. Konstatiramo pri tome da - za razliku od Hrvat-

Vidjeti: UN, Department of Economic and Social Affairs, World Population Prospects, The 2015 Revision, Vol. I, New York, 2014 
ske, u kojoj u navedenom razdoblju proces razvoja ukupnog stanovništva bitno obilježava proces prirodne depopulacije $-\mathrm{u}$ većini zapadnoeuropskih zemalja proces prirodne depopulacije nije zabilježen. Prirodno kretanje njihova stanovništva obilježava upravo suprotno - prirodni prirast.

Prirodna depopulacija $\mathrm{u}$ određenoj zemlji označava prirodno izumiranje, prirodno nestajanje stanovništva, koje se $u$ tzv. zatvorenom tipu populacije ${ }^{6}$ događa u uvjetima kada broj umrlih osoba kontinuirano i dugoročno nadvisuje broj živorođene djece. Pri tome treba imati na umu demografsku zakonitost da se prirodna depopulacija snagom demografskog momentuma, demografske inercije, u području promjena u dobnoj strukturi stanovništva, intenzivira osobito u demografskim uvjetima regresivnog tipa dobne strukture. Taj je tip već nekoliko desetljeća bitna karakteristika dobne strukture stanovništva Hrvatske, ali i svih onih zemalja koje se nalaze u posttranzicijskoj etapi razvoja stanovništva i u kojima traje proces prirodne depopulacije. ${ }^{7}$ Tako se pokazuje da $\mathrm{u}$ Hrvatskoj stopa nataliteta/fertiliteta stalno opada (nakon 2010. godine smanjena je ispod 10 promila s tendencijom daljnjeg pada), dok druga sastavnica prirodne promjene, stopa mortaliteta, prosječno uzevši, stabilno stagnira na relativno niskoj razini (oko 9 - 10 promila) s tendencijom blagog porasta, što je uvjetovano intenzivnim starenjem populacije koje uvjetuje stalno smanjivanje mladog stanovništva (0 - 15 godina) i produženje očekivanog trajanja života. Takva dinamika sastavnica prirodnog kretanja stanovništva dovela je do stope prirodnog smanjenja (negativna stopa prirodnog „prirasta“), koja je postala karakteristična za Hrvatsku. - Valja naglasiti da nasuprot tome, u velikoj većini navedenih zapadnoeuropskih zemalja, stopa prirodne promjene stanovništva ima pozitivan predznak, što znači da razvoj njihova stanovništva obilježava stopa prirodnog

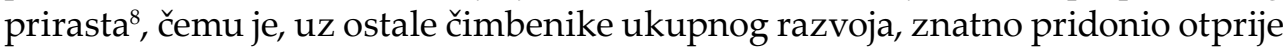
postojeći pozitivan migracijski saldo.

U kontekstu navedene usporedbe osobito je instruktivno i zanimljivo razmatranje koje se odnosi na promjenu strukture sastavnica koje određuju konačan rezultat demografskih promjena u pojedinim zapadnoeuropskim zemljama i u

6 Prema postojećoj demografskoj tipologiji, zatvoreni tip populacije označava razvoj stanovništva određene zemlje u uvjetima kada se apstrahira od utjecaja migracije (uz pretpostavku da nema migracije).

7 Depopulacijske demografske promjene, osobito pad nataliteta i negativan prirodni „prirast“, ali i smanjivanje ukupnog broja stanovništva, događaju se nakon sloma komunizma i u drugoj grupi europskih zemalja članica EU-28, a to su uglavnom istočnoeuropske, bivše socijalističke zemlje.

8 U 2012. godini (između 1.1. 2012. i 2013.) ta je stopa bila u okviru razmatranih zapadnoeuropskih zemalja negativna jedino u Njemačkoj i Italiji te u najnovije doba i u Austriji (Eurostat, Demography report 2013). 
Hrvatskoj. A činjenica je da su strukturne demografske promjene kao i čimbenici koji determiniraju konačan rezultat demografskih promjena u određenoj zemlji i u određenom razdoblju, konkretno između navedenih zapadnoeuropskih zemalja i Hrvatske, signifikantno različiti. To se izražava kako kvantitativno u konačnom brojčanom rezultatu promjene ukupnog broja stanovnika (porast, stagnacija, smanjenje), tako i kvalitativno - u promjeni strukture i strukturnog sadržaja nastale promjene. U pitanju je kvantitativna promjena, $\mathrm{tj}$. promjena $\mathrm{u}$ ukupnom broju stanovnika, koja je određena sastavnicama demografske bilance, koje su međusobno u stalnoj interakciji. To zorno prezentira analitička razrada demografske bilance u navedenim zapadnoeuropskim zemljama i u Hrvatskoj.

Bitno obilježje navedenih zapadnoeuropskih zemalja jest da su to zemlje imigracije, da imaju demografski značajan pozitivan saldo migracije, da imigracija brojčano nadvisuje emigraciju, dok je Hrvatska dugotrajno, već od posljednjih desetljeća 19. stoljeća, emigracijska zemlja - emigracija nadvisuje imigraciju, migracijski je saldo negativan. Činjenica je da se u razdoblju nakon Drugog svjetskog rata u razvoju stanovništva Hrvatske gotovo trajno održalo, uz povremene oscilacije, emigracijsko obilježje i značajke demografske bilance.

U 1960-im i 1970-im godinama migraciju u Hrvatskoj bitno obilježava tip tzv. privremene ekonomske emigracije, u 1980-im godinama karakteristična je emigracija koju obilježava reunifikacija (sjedinjavanje) obitelji naših „privremenih“ emigranata, u 1990-im godinama emigracija je pretežno pod utjecajem eksternih čimbenika povezanih prvenstveno uz Domovinski rat, a početkom 21. stoljeća, između 2008. i 2015. godine, emigracija je pojačana napose pod utjecajem ekonomske krize i s tim u vezi pod utjecajem porasta ukupne nezaposlenosti, osobito nezaposlenosti mladih. Tada emigracijsko obilježje demografske bilance Hrvatske postaje još jače izraženo. Tako je u tijeku prvog i drugog desetljeća 21. stoljeća signifikantno povećana razlika između strukture demografske bilance Hrvatske (u kojoj je bitno značenje imala emigracija) i strukture te bilance u zapadnoeuropskim zemljama u kojima je njezina temeljna dinamička sastavnica i nadalje ostala imigracija, a pozitivan migracijski saldo (uz prirodni prirast) sve više postaje temeljna odrednica njihove demografske bilance, odnosno pridonosi sve većim brojem i udjelom porastu ukupnog broja stanovnika tih zemalja.

U Hrvatskoj je stanje u tom pogledu obratno, jer negativni migracijski saldo i uz dugotrajno postojeći negativni prirodni „prirast,“ sve više postaje bitna odrednica smanjivanja ukupnog broja stanovnika. Takve diferencijalne značajke udjela migracijskog salda u formiranju konačnog rezultata demografske bilance u navedenim zapadnoeuropskim zemljama, s jedne strane, i u Hrvatskoj, s druge, postaju sve važnije za diferencijalni ukupni i strukturni razvoj stanovništva tih zemalja u 21. stoljeću. 
Rad Hrvat. akad. znan. i umjet. Razred za druš. znan. 52=529(2017) : 1-28

\section{DEMOGRAFSKA BILANCA I NJEZINE SASTAVNICE U HRVATSKOJ I U ZAPADNOEUROPSKIM ZEMLJAMA}

Diferencijalna struktura demografske bilance zapadnoeuropskih zemalja i Hrvatske odraz je diferencijalnih bitnih čimbenika demografskog i društvenoekonomskog razvoja tih zemalja koji su oblikovali njihove temeljne demografske promjene. Pri analizi demografske bilance na prvome je mjestu potrebno izvršiti raščlambu bilance na njezine temeljne demografske sastavnice. Važno je pri tome naglasiti da su te sastavnice $u$ danim razvojnim uvjetima $u$ određenoj zemlji i u određenom razdoblju pod utjecajem vrlo različitih, kako općih tako i specifičnih, prije svega razvojnih, ali i drugih, često i tzv. eksternih čimbenika. Radi se o ekonomskim, socijalnim, zdravstvenim, obrazovnim, prostornim, povijesnopolitičkim, socio-psihološkim i drugim čimbenicima koji u određenom razdoblju djeluju na razvoj stanovništva određene zemlje. Analizirat ćemo sastavnice demografske bilance u izabranim zapadnoeuropskim zemljama i u Hrvatskoj, a u tom kontekstu i demografske promjene koje su se dogodile u 2012. godini (između 1.1.2012. i 1.1.2013. godine). Valja naglasiti da strukturne promjene zabilježene u toj godini korespondiraju s ranije evidentiranim strukturnim promjenama, napose onima koje su se dogodile u prvom desetljeću 21. stoljeća, i da su dobar demografsko-statistički reprezentant ukupnog brojčanog rezultata tih promjena.

Demografska bilanca, kao i svaka druga bilanca, ima svoju stranu aktive i pasive koje obuhvaćaju one sastavnice ukupnog kretanja stanovništva koje, uz ostale iste čimbenike i uvjete, zajednički djeluju na konačni rezultat bilance, tj. na porast, stagnaciju ili smanjenje ukupnog broja stanovnika određene zemlje. Čine ih dvije grupe sastavnica: sastavnice prirodne promjene, natalitet/fertilitet $\mathrm{i}$ mortalitet te sastavnice migracijske promjene, imigracija i emigracija. Iz analitičkih, ali i iz sadržajnih razloga te sastavnice dijelimo na pozitivne i negativne sastavnice/odrednice promjene demografske bilance. Pozitivne sastavnice na strani aktive demografske bilance čine natalitet/fertilitet i imigracija kao pozitivne komponente moguće promjene ukupnog broja stanovnika, kojih porast, uz ostale nepromijenjene čimbenike, djeluje na porast ukupnog broja stanovnika i vice versa. Negativne sastavnice na strani pasive demografske bilance čine mortalitet i emigracija, znači one komponente promjene ukupnog broja stanovnika koje, uz ostale nepromijenjene uvjete, djeluju na smanjenje ukupnog broja stanovnika i vice versa. ${ }^{9} \mathrm{Uz}$ navedene četiri bitne pojedinačne sastavnice demografske bilance

\footnotetext{
U detaljnijoj analizi demografske bilance često se rabe pojmovi ", horizontalne“ i vertikalne“ sastavnice, a u određenim istraživanjima i pojmovi „dijagonalne“ sastavnice demografske bilance, "agregatne" i „sumarne“ sastavnice i sl.
} 
analitički su značajne dvije agregatne (sumarne, izvedene) sastavnice, a to su prirodna promjena (prirodni prirast ili prirodno smanjenje) i migracijska promjena (migracijski saldo, pozitivan ili negativan).

Pri tome su za konačni rezultat promjene demografske bilance $u$ danoj zemlji i u danom razdoblju, koji se izražava nastalom promjenom ukupnog broja stanovnika u toj zemlji i u tom razdoblju, bitni kvantitativni odnosi između sve četiri temeljne sastavnice demografske bilance ili, drugim riječima, kvantitativni odnosi između pozitivnih i negativnih sastavnica demografske bilance. Porast ili smanjenje ukupnog broja stanovnika, bitno i izravno ovisi o kvantitativnom međuodnosu pozitivnih i negativnih sastavnica bilance, koje čine četiri navedene pojedinačne sastavnice demografske bilance. Taj kvantitativni međuodnos pojedinih sastavnica demografske bilance, pozitivnih i negativnih, nije međutim konstantan, on se stalno mijenja. Taj je međuodnos stoga kompleksan i promjenjiv u vremenu i prostoru, ovisno o promjeni čimbenika koji ih u danim uvjetima određuju, a time i o jačini utjecaja pojedine sastavnice/sastavnica demografske bilance te istovremeno i o stalnoj interakciji između tih sastavnica, kako onih na strani aktive, tako i onih na strani pasive bilance. Konačni kvantitationi rezultat njihova međuodnosa koji se izražava u promjeni ukupnog broja stanovnika (njegovim porastom, stagnacijom ili smanjenjem) u određenom vremenu i prostoru ovisi o promjeni demografskih, društveno-ekonomskih, zdravstvenih, prostornih, povijesno-političkih i drugih razvojnih uvjeta i čimbenika.

Načinimo li detaljniju raščlambu demografske bilance na njezine sastavnice, pokazuje se da između razmatranih zapadnoeuropskih zemalja i Hrvatske postoje $\mathrm{u}$ tom pogledu bitne razlike. Usporedimo li demografske bilance pojedinih zapadnoeuropskih zemalja s demografskom bilancom Hrvatske u 2012. godini, prvenstveno njihovu strukturu prema navedenim sastavnicama, pokazuje se znatna razlika između spomenutih zemalja i Hrvatske, koja se iskazuje agregatno i strukturno. Prvo, Hrvatska nakon 1990. godine pokazuje sljedeće značajke: negativnu ukupnu demografsku bilancu, jer ima ukupnu depopulaciju, odnosno njezin se agregatni kvantitativni rezultat iskazuje u smanjivanju ukupnog broja stanovnika. Drugo, Hrvatska istovremeno bilježi i prirodnu depopulaciju uvjetovanu većim brojem umrlih osoba u odnosu na broj živorođene djece (negativnu prirodnu promjenu, prirodno smanjenje stanovništva) koja, uz ostale nepromijenjene uvjete i uz uvjet da traje dovoljno dugo (a u Hrvatskoj traje već dva i pol desetljeća), označava izumiranje, nestajanje stanovništva. Treće, Hrvatska istovremeno bilježi i negativan migracijski saldo, koji je uvjetovan većim brojem iseljenih osoba u odnosu na broj doseljenih i indikator je niske razine ekonomskog razvoja u odnosu na razmatrane zapadnoeuropske zemlje. Činjenica je pri tome 
da se negativni migracijski saldo Hrvatske, napose zbog gospodarske recesije nakon 2008. godine, izrazito povećao. Determinira ga sve veći broj iseljenih osoba ne samo u zapadnoeuropske zemlje već i u prekomorske zemlje, a emigracija uvjetuje pogoršanje demografskih i ekonomsko-socijalnih obilježja i struktura autohtonog stanovništva naše zemlje. Odlaze pretežno mladi, visokoobrazovani ljudi, konjunkturnih suvremenih zanimanja za kojima postoji visoka potražnja u visokorazvijenim zemljama koje su zemlje destinacije za ekonomske emigrante.

Treba naglasiti da u Hrvatskoj obje strane demografske bilance, strana aktive i strana pasive, sadrže sastavnice koje svojim promjenama u određenom razdoblju, a pod utjecajem prvenstveno brojnih društveno-ekonomskih, ali i mnogih drugih često specifičnih čimbenika, uvjetuju demografske promjene kojih je rezultat proces ukupne depopulacije koji u nas traje četvrt stoljeća, između 1990. i 2015. godine. Drugim riječima, u Hrvatskoj sve četiri pojedinačne sastavnice demografske bilance u svom kvantitativnom međuodnosu dinamičkih promjena $\mathrm{u}$ određenom vremenu, izravno uvjetuju proces ukupne depopulacije. Te sastavnice u svojoj stalnoj interakciji i specifičnoj dinamici djelovanja u određenom razdoblju također izravno uvjetuju i prirodno smanjenje stanovništva i negativan migracijski saldo. Prirodno smanjenje stanovništva kao endogeni demografski proces karakterističan za posttranzicijsku etapu razvoja stanovništva ${ }^{10}$, odnosno za njezine pojedine podetape, znatno je pod utjecajem socio-bioloških, a u suvremenom svijetu sve više je pod utjecajem, uz otprije djelujuće ekonomsko-socijalne uvjete i čimbenike, napose socio-psihološke, novih svjetonazorskih čimbenika (tzv. proces „druge demografske tranzicije“). Za razliku od prirodnog smanjenja stanovništva, negativan migracijski saldo pretežno je pod utjecajem druge vrste čimbenika, ponajprije pod utjecajem čimbenika društveno-ekonomskog razvoja u najširem značenju toga pojma. To je temeljna differentia specifica između čimbenika koji uvjetuju prirodno kretanje stanovništva i migracijsko (mehaničko) kretanje stanovništva.

Proces ukupne depopulacije $\mathrm{u}$ demografskim uvjetima ubrzanog starenja dobne strukture stanovništva, procesa koji u Hrvatskoj traje već od početka 1970ih godina, ${ }^{11}$ znači izumiranje, nestajanje stanovništva. Taj je demografski proces temeljna značajka sadašnje demografske situacije u Hrvatskoj koja, ceteris paribus, dugoročno determinira buduće demografske trendove, kako agregatne tako i strukturne.

10 Vidjeti, Van de Kaa, D., Europe's Second Demographic Transition, Population Bulletin, Vol 42, No 1, 1987, Washington D.C.

11 Vidjeti, Wertheimer-Baletić,A., Demografski okviri ponude radne snage u Jugoslaviji, Ekonomist br 1-2/ 1974; također, __ , Ekonomski aktivno stanovništvo SR Hrvatske - stanje i tendencije, Ekonomski pregled br.11-12/1983, Zagreb 
Usporedba sastavnica demografske bilance zapadnoeuropskih zemalja i Hrvatske pokazuje (kako smo već naglasili) podudarnost smjera promjene, ali samo kod prirodne dinamike stanovništva, preciznije rečeno samo kod sastavnica prirodne promjene stanovništva, napose u području smanjivanja nataliteta/fertiliteta i mortaliteta. Ta podudarnost smjera promjene međutim ne postoji kod sastavnica migracijske promjene, odnosno kod „migracijske depopulacije." Pokazuje se naime da nakon 1965. godine natalitet/fertilitet u navedenim zapadnoeuropskim zemljama, isto kao i u Hrvatskoj, ima, prosječno uzevši, isti smjer promjene koja se izražava u tendenciji njegova smanjivanja. Istovremeno mortalitet (opći i specifični prema dobi) pokazuje tendenciju stabilizacije ili čak blagog porasta, što je primarno uvjetovano starenjem stanovništva i produljenjem očekivanog trajanja života, dakle procesima koji dolaze do izražaja i u navedenim zapadnoeuropskim zemljama i u Hrvatskoj. Međutim, kada je u pitanju usporedba ukupne migracijske promjene (migracijskog salda) uvjetovane međuodnosom sastavnica ukupne migracije (imigracije i emigracije), pokazuje se da između navedenih zapadnoeuropskih zemalja i Hrvatske postoji izrazita razlika. U Hrvatskoj opći trend pokazuje da je imigracija kvantitativno niska ili se tek privremeno evidentira njezin porast, ali u dugoročnom razdoblju, tijekom cijeloga 20. i početkom 21. stoljeća, napose između 2008. i 2015. godine, migracijski saldo bilježi negativan predznak. To se događa pod utjecajem značajne suvremene emigracije iz Hrvatske kao tradicionalno poznate zemlje emigracije, koja ima dugoročni, stoljetni trend porasta još od 1880-ih godina. U 21. stoljeću do sada je osobito izražena u najnovijem kriznom razdoblju (nakon 2008. godine). ${ }^{12}$ Povezano uz permanentno visoku nezaposlenost i pad zaposlenosti tijekom posljednje dvije godine (2014. i 2015.), iz Hrvatske masovno odlaze mladi visokokvalificirani ljudi traženih konjunkturnih zanimanja, i to sve više s djecom, odnosno s članovima obitelji. Stoga je ukupni migracijski saldo u Hrvatskoj negativan pod jakim utjecajem emigracije, koja ima tendenciju povećavanja. Nasuprot tome, u razmatranim zapadnoeuropskim zemljama migracijski je saldo pozitivan, imigracija znatno nadvisuje emigraciju, što je osobito naglašeno tijekom prvog i do polovice drugog desetljeća 21. stoljeća (između 2000. i 2015. godine).

2 Prema podacima Državnog zavoda za statistiku RH za godinu 2014. iz Hrvatske je u inozemstvo iselilo 20.858 osoba, od kojih su 94 \% državljani Hrvatske. Međutim, poznato je da su naši podaci u statistici migracija, a napose o emigraciji, vrlo nepouzdani, primarno zbog toga što se ne temelje na podacima o odjavi prebivališta. Osim toga valja imati na umu da odjava prebivališta pri odlasku u inozemstvo službeno nije uvjet za odlazak (iseljenje) u inozemstvo. Može se prema tome s visokim stupnjem pouzdanosti pretpostaviti da je iz Hrvatske u 2014. i 2015. godini iselilo dva do tri puta više ljudi nego što bilježi službena statistika migracije (tzv. „ilegalno“ iseljeni). 
Svjedoci smo velike „seobe naroda“, uglavnom iz zemalja Bliskog istoka i sjeverne Afrike, koja je usmjerena ponajprije u Njemačku, zatim u Švedsku, Veliku Britaniju i Francusku, a uvjetovana je ratovima i željom za „boljim životom.“ S time u vezi možemo s visokim stupnjem pouzdanosti predvidjeti daljnje jačanje imigracijske sastavnice kao determinante porasta ukupnog broja stanovnika u navedenim zapadnoeuropskim zemljama, za razliku od Hrvatske, koja sve više postaje zemlja u kojoj usporedno s prirodnim smanjenjem stanovništva jača emigracijska sastavnica demografske bilance kao determinanta daljnjeg smanjivanja ukupnog broja stanovnika.

\section{TIPOLOGIJA STRUKTURE DEMOGRAFSKE BILANCE U HRVATSKOJ I U ZAPADNOEUROPSKIM ZEMLJAMA}

Instruktivno je nadalje analizirati strukturu demografske bilance zapadnoeuropskih zemalja na primjerima navedenih, odnosno izabranih zemalja te prezentirati karakteristike strukture demografske bilance u tim zemljama u usporedbi s demografskom bilancom Hrvatske. Podaci se odnose na 2012. godinu (razdoblje 1.1.2012. - 1.1.2013.), koja se u većini zapadnoeuropskih zemalja pokazala statistički reprezentativnom za dugoročne demografske promjene, osobito za one koje su se u navedenim zemljama dogodile tijekom posljednjeg desetljeća 20. stoljeća i prvog desetljeća 21. stoljeća.

Ako 18 navedenih (razmatranih) zapadnoeuropskih zemalja ${ }^{13}$ razvrstamo prema predznaku promjene ukupnog broja stanovnika (porast, smanjenje) koja se dogodila u tom razdoblju, razlikujemo dvije grupe zemalja. Prvu grupu čini 15 zemalja koje su u 2012. godini zabilježile porast ukupnog broja stanovnika (Belgija, Danska, Njemačka, Irska, Francuska, Italija, Luksemburg, Nizozemska, Austrija, Finska, Švedska, Velika Britanija, Slovenija, Norveška i Švicarska). Drugu grupu čine 3 zemlje (Portugal, Španjolska i Hrvatska) u kojima je te godine zabilježen negativan predznak promjene ukupnog broja stanovnika, odnosno smanjenje ukupnog broja stanovnika (vidjeti tablicu $1 \mathrm{u}$ prilogu).

\footnotetext{
$\overline{13}$ Da ponovimo - to su slijedeće zemlje: Belgija, Danska,Njemačka, Irska, Francuska, Italija, Luksemburg, Nizozemska, Austrija, Finska, Švedska, Velika Britanija, Slovenija, Norveška i Švicarska, Španjolska, Portugal i Hrvatska.
} 
PRILOG - Tablica 1

Demografska bilanca Hrvatske i odabranih zapadnoeuropskih zemalja (1.1.2012. - 1.1.2013.)

\begin{tabular}{|c|c|c|c|c|c|c|c|}
\hline Zemlja & $\begin{array}{c}\text { Ukupan broj } \\
\text { stanovnika } \\
\text { (u 000) } \\
(1.1 .2012 .)\end{array}$ & $\begin{array}{c}\text { Broj } \\
\text { živorođenih } \\
(\check{Z} R)\end{array}$ & $\begin{array}{l}\text { Broj } \\
\text { umrlih } \\
(\mathrm{M})\end{array}$ & $\begin{array}{c}\text { Prirodni } \\
\text { prirast/ } \\
\text { pad }\end{array}$ & $\begin{array}{c}\text { Neto } \\
\text { migracija }\end{array}$ & $\begin{array}{c}\text { Ukupna } \\
\text { promjena } \\
(1.1 .2012 .- \\
1.1 .2013 .)\end{array}$ & $\begin{array}{c}\text { Ukupni broj } \\
\text { stanovnika (u } \\
\text { 000) (1.1.2013.) }\end{array}$ \\
\hline Austrija & $8.408,1$ & 79,0 & 79,4 & $-0,5$ & $+44,2$ & $+43,7$ & $8.451,9$ \\
\hline Belgija & $11.094,9$ & 128,1 & 109,1 & $+19,0$ & $+47,8$ & $+66,8$ & $11.161,6$ \\
\hline Danska & $5.850,5$ & 57,9 & 52,3 & $+5,6$ & $+16,5$ & $+22,1$ & $5.602,6$ \\
\hline Finska & $5.401,3$ & 59,5 & 51,7 & $+7,8$ & $+17,6$ & $+25,4$ & $5.406,7$ \\
\hline Francuska & $65.327,7$ & 822,9 & 571,2 & $+251,7$ & $+53,8$ & $+305,5$ & $65.633,2$ \\
\hline Irska & $4.582,7$ & 72,2 & 28,8 & $+43,4$ & $-35,0$ & $+8,4$ & $4.591,1$ \\
\hline Italija & $59.394,2$ & 534,2 & 612,9 & $-78,7$ & $+369,7$ & $+291,0$ & $59.685,2$ \\
\hline Luksemburg & 524,3 & 6,0 & 3,9 & $+2,2$ & $+10,0$ & $+12,2$ & 537,0 \\
\hline Nizozemska & $16.730,3$ & 176,0 & 140,8 & $+35,1$ & $+14,1$ & $+49,2$ & $16.779,6$ \\
\hline Norveška & $4.985,9$ & 60,3 & 42,0 & $+18,3$ & $+47,1$ & $+65,4$ & $5.051,3$ \\
\hline Njemačka & $80.327,9$ & 673,2 & 869,6 & $-196,0$ & $+391,9$ & $+195,8$ & $80.323,7$ \\
\hline Portugal & $10.542,4$ & 89,8 & 107,6 & $-17,8$ & $-37,3$ & $-55,1$ & $10.487,3$ \\
\hline Slovenija & $2.055,5$ & 21,9 & 19,3 & $+2,7$ & $+0,6$ & $+3,3$ & $2.055,8$ \\
\hline Švedska & $9.482,9$ & 113,2 & 91,9 & $+21,2$ & $+51,8$ & $+73,0$ & $9.555,9$ \\
\hline Švicarska & $7.954,7$ & 82,2 & 64,2 & $+18,0$ & $+66,4$ & $+84,4$ & $8.039,1$ \\
\hline Španjolska & $46.818,8$ & 452,3 & 403,8 & $+48,5$ & $-162,4$ & $-113,9$ & $46.704,3$ \\
\hline V. Britanija & $63.495,4$ & 813,0 & 569,0 & $+243,9$ & $+148,7$ & $+392,6$ & $63.888,0$ \\
\hline Hrvatska & $4.276,0$ & 41,8 & 51,7 & $-9,9$ & $-3,9$ & $-13,8$ & $4.262,1$ \\
\hline
\end{tabular}

Izvor: Eurostatnewsrelease, 20. studenoga 2013.

U okviru prve grupe zemalja, odnosno onih koje su zabilježile porast stanovništva, razlikujemo dvije podgrupe. U prvoj podgrupi na porast ukupnog broja stanovnika djelovale su obje sastavnice ${ }^{14}$ demografske bilance, prirodna i migracijska, uz napomenu da su obje sastavnice imale isti (pozitivan) predznak. Prirodnu promjenu koju obilježava pozitivan predznak označava prirodni prirast,

$\overline{14}$ Prirodna sastavnica podrazumijeva rezultat kvantitativnog odnosa između nataliteta i mortaliteta, a odnosi se u konkretnom slučaju na prirodni prirast, prirodnu stagnaciju ili prirodno smanjenje stanovništva određene zemlje. 
a drugu, migracijsku promjenu koja ima također pozitivan predznak označava pozitivan migracijski saldo. Pri tome je ona sastavnica koja je u određenoj zemlji imala brojčano veći ponder imala razumljivo dominantnu ulogu, odnosno bitno je utjecala na veličinu porasta ukupnog broja stanovnika. U drugoj podgrupi $\mathrm{u}$ okviru prve grupe zemalja nalaze se one zemlje u kojima je ukupni broj stanovnika također zabilježio porast i u kojima je kvantitativni međuodnos sastavnica demografske bilance doveo također do porasta ukupnog broja stanovnika, ali je pri tome bitno naglasiti da su navedene sastavnice demografske bilance imale različit predznak (npr. prirodni prirast i negativni migracijski saldo, ili prirodno smanjenje stanovništva i pozitivan migracijski saldo). U pojedinim zemljama u drugoj podgrupi porast stanovništva bio je stoga rezultat međudjelovanja obiju sastavnica demografske bilance, ali je jedna od njih djelovala na porast, a druga istovremeno na smanjenje ukupnog broja stanovnika. To znači da su obje sastavnice bilance istovremeno djelovale na veličinu porasta ukupnog broja stanovnika, ali je njihovo djelovanje bilo u međusobno suprotnom smjeru. Važno je međutim da je jedna od sastavnica, bilo prirodna bilo migracijska, i to ona koja je imala pozitivan predznak, imala brojčano veći ponder i stoga je u konačnici, odnosno u konačnom rezultatu, uvjetovala u određenoj zemlji i u određenom razdoblju porast ukupnog broja stanovnika.

U prooj podgrupi u okviru prve grupe zapadnoeuropskih zemalja nalaze se, kako smo već naveli, one zemlje koje su u 2012. godini zabilježile porast ukupnog broja stanovnika, koji su uvjetovale obje sastavnice demografske bilance, jer su obje imale pozitivan predznak. Radi se o sljedećih 10 zemalja: Belgija, Danska, Francuska, Luksemburg, Nizozemska, Finska, Švedska, Norveška, Velika Britanija i Švicarska.

$\mathrm{U}$ drugoj podgrupi u okviru prve grupe zapadnoeuropskih zemalja, u kojoj je također zabilježen porast ukupnog broja stanovnika, a u kojoj su sastavnice demografske bilance imale međusobno različit predznak, valja razlikovati dvije karakteristične skupine zemalja: /a/ zemlje kod kojih je na porast ukupnog broja stanovnika dominantan utjecaj imao pozitivni migracijski saldo, i /b/ zemlje $\mathrm{u}$ kojima je dominantan utjecaj na porast ukupnog broja stanovnika imao prirodni prirast stanovništva. Činjenica je da je u većini tih zemalja pozitivni migracijski saldo imao relativno veći ponder od prirodnog prirasta i prema svom brojčanom udjelu nadvisio je udjel prirodnog prirasta u ukupnom porastu stanovništva. U visokorazvijenim europskim zemljama koje u suvremenom razdoblju razvoja stanovništva obilježava posttranzicijska etapa u razvoju stanovništva to je opća karakteristika promjene ne samo strukture već i dinamike obiju navedenih sastavnica demografske bilance. Pri tome je visok pozitivan migracijski saldo u de- 
mografskoj bilanci određene zemlje redovito značajan pokazatelj visoke razine dostignutog ekonomskog razvoja i vice versa.

U pravilu je određeni kvantitativni odnos prirodnih i migracijskih sastavnica demografske bilance uvjetovao da su navedene zemlje u kojima obje sastavnice obilježava pozitivan predznak imale izrazitu imigracijsku karakteristiku, bile su zemlje imigracije. Takve značajke pretežnog utjecaja pozitivnog migracijskog salda na porast ukupnog broja stanovnika pokazalo je u navedenom razdoblju 7 zemalja. ${ }^{15}$ To su: Belgija, Danska, Luksemburg, Finska, Švedska, Norveška i Švicarska. Za tu podgrupu zapadnoeuropskih zemalja karakteristično je da su zabilježile istovremeno s pozitivnim migracijskim saldom i pozitivnu prirodnu promjenu, odnosno prirodni prirast stanovništva, koji je međutim bio brojčano manji od pozitivnog migracijskog salda i slabijim je intenzitetom djelovao na iskazani porast ukupnog broja stanovnika u 2012. godini, odnosno pridonio mu je. To su zemlje s visokim stopama ekonomskog rasta i razvoja, s visokom razinom životnog standarda, visokom stopom zaposlenosti, niskom stopom nezaposlenosti itd., koje su postale privlačna destinacija za stranu radnu snagu. Glavni cilj selektivne migracijske politike navedenih zapadnoeuropskih zemalja bio je „uvoz" radne snage koja, prema broju i strukturi, napose strukturi prema djelatnosti, zanimanju i obrazovanju, odgovara njihovoj potražnji za radnom snagom.

Nadalje ćemo u navedenim podgrupama zemalja, koje pripadaju prvoj grupi zemalja koja je u navedenom razdoblju zabilježila porast stanovništva, analitički razmotriti, i to u pojedinim izabranim reprezentativnim zemljama, strukturu demografske bilance s gledišta veličine udjela, a time i značenja udjela prirodnog prirasta i pozitivnog migracijskog salda u zabilježenom ukupnom porastu njihova stanovništva u navedenoj godini.

Za prvu podgrupu zemalja koje se nalaze u okviru prve grupe analiza pokazuje da je u 2012. godini pozitivni migracijski saldo sudjelovao u ukupnom porastu stanovništva s visokim udjelom koji se kretao u rasponu 70\% - 90\% (70,9\% Švedska i 89,9\% Luksemburg). Uzmimo primjer Švedske, koja ima dugotrajan i stabilan priljev strane radne snage i koja dugoročno (već od 1930-ih godina) uspješno provodi tzv. implicitnu populacijsku i obiteljsku politiku. ${ }^{16} \mathrm{U}$ Švedskoj

$\overline{15}$ Pozitivan migracijski saldo uvjetovao je porast ukupnog broja stanovnika i u nekim zemljama koje su u 2012. godini imale negativnu prirodnu promjenu stanovništva (negativnu stopu prirodnog „prirasta“), kao što su Njemačka i Italija, ali one su u ovom radu u okviru prve grupe zemalja svrstane u drugu podgrupu zemalja (u kojima su sastavnice demografske bilance imale različit predznak).

Vidjeti: Höem, B. (2000), Entry into motherhood in Sweden: the influence of economic factors on the rise and fall in fertility, 1986-1997, Demographic Research 2(4); također, Höem, J. M. (1986), The impact of education on modern fertility, European Journal of Population, no. 2; zatim, Höem, J.M. (1993), Public Policy as the fact in fertility: Effects of the Policy Reform on the Pace of Childbearing in Sweden 1n 1980's, Acta sociologica, 3 (6) 
je u 2012. godini migracijski saldo bio glavna odrednica porasta ukupnog broja stanovnika, koji je tada iznosio 73.000. U njemu je migracijski saldo sudjelovao s 51.800 ili $70,9 \%$, a prirodni prirast s 21.200 ili $29,1 \%$. Proizlazi da je pozitivan migracijski saldo tada bio oko 2,5 puta veći od prirodnog prirasta stanovništva i bio je izrazito dominantna odrednica porasta ukupnog broja stanovnika te zemlje. U tom kontekstu zanimljiv je i primjer Luksemburga, koji je te godine imao relativno najveći raspon varijacije između veličine udjela pozitivnog migracijskog salda i prirodnog prirasta u ukupnom porastu stanovništva. Pozitivni migracijski saldo bio je čak oko 4,5 puta veći od prirodnog prirasta stanovništva, a u porastu ukupnog broja stanovnika Luksemburga te je godine imao vrlo visok udjel; sudjelovao je gotovo s $90 \%$ (89,9\%) u porastu ukupnog broja stanovnika. Također je i kod drugih navedenih zapadnoeuropskih zemalja iz te podgrupe jasno vidljiva visoka pozitivna korelacija između stope porasta ukupnog broja stanovnika i veličine udjela pozitivnoga migracijskog salda.

U prvu podgrupu u okviru navedene prve grupe zemalja, znatno manju prema broju obuhvaćenih zemalja koje su 2012. godine zabilježile porast ukupnog broja stanovnika, ulaze još četiri zemlje: Francuska, Nizozemska, Velika Britanija i Slovenija. Specifičnost je primarno prve tri zemlje da je porast ukupnog broja stanovnika također bio pod utjecajem obiju pozitivnih sastavnica demografske bilance, s tom razlikom što je pretežan utjecaj na porast ukupnog broja stanovnika imao u tim zemljama prirodni prirast stanovništva, koji je svojim udjelom $\mathrm{u}$ porastu njihova ukupnog stanovništva nadvisio pozitivni migracijski saldo. U tom relativno višem prirodnom prirastu navedenih zemalja sadržan je utjecaj relativno višeg nataliteta i prirasta kao posljedica ranije imigracije stanovništva iz slabije razvijenih zemalja, većinom bivših kolonija. Prirodni prirast stanovništva kod prve tri zemlje, osobito kod Francuske, u velikoj je mjeri i odraz dugotrajno postojeće pronatalitetne populacijske politike, uvjetovane već otprije (od kraja 18. stoljeća) u odnosu na druge zapadnoeuropske zemlje relativno niskim prirodnim prirastom pod utjecajem izrazito niskog nataliteta, koji je uz relativno stabilan, srednje visok mortalitet, rezultirao određenim vremenskim pomakom, u promjenama dobne strukture stanovništva s niskim prirastom radnog kontingenta stanovništva. Stoga je bio u diskrepanciji sa zahtjevima i veličinom, a osobito sa strukturom potražnje za radnom snagom u tim zemljama. S tim u vezi djelovao je kao poticajni, privlačni čimbenik (pull faktor) za priljev radnosposobnog stanovništva iz inozemstva (uglavnom iz bivših francuskih kolonija). Inače, kako je poznato, u navedenim je zemljama, tj. u Francuskoj, Velikoj Britaniji i Nizozemskoj, kao zemljama metropolama bivših kolonija, proces demografske tranzicije u području nataliteta nastupio znatno ranije, što je bio odraz njihove 
relativno više razine ekonomskog razvoja i pratećih društvenih promjena, napose procesa modernizacije društva.

Relativno visok pozitivan migracijski saldo, uz ostale nepromijenjene čimbenike, djelovao je tijekom godina i na sadašnju relativno višu razinu nataliteta/ fertiliteta u Francuskoj, u kojoj je npr. u 2014. godini totalna stopa fertiliteta bila gotovo na razini reprodukcijski ,zamjenske“ stope (iznosila je 2,01) s tendencijom daljnjeg blagog povećanja. Ta je stopa tada u Švedskoj iznosila 1,91, u Velikoj Britaniji 1,92, u Nizozemskoj 1,72, što je iznad prosječne totalne stope fertiliteta u ostalim navedenim zapadnoeuropskim zemljama koja je tada iznosila 1,6. Stopa nataliteta $u$ tri navedene zemlje između 2005. i 2014. kretala se u rasponu varijacije 12 - 13 promila i bila je iznad prosječne stope nataliteta za razmatrane zapadnoeuropske zemlje (koja je iznosila do 10 promila). Osim toga, te su zemlje, povezano upravo uz nizak natalitet i prirodni prirast te dinamičan ekonomski razvoj, relativno ranije iskazale povećanu potražnju za radom i postale uvoznice radne snage (osobito iz zemalja bivših kolonija). U Francuskoj je dugoročna, kontinuirana i stabilna pronatalitetna populacijska politika, uz relativno dugotrajan priljev, odnosno uvoz strane radne snage, djelovala na recentnu restriktivnu politiku uvoza strane radne snage (smanjivanja tzv. kvota uvoza). Stabilna i uspješna pronatalitetna populacijska politika dala je u tim okolnostima relativno veće značenje povećanoj razini nataliteta i prirodnoga prirasta autohtonog stanovništva u formiranju porasta ukupnog broja stanovnika Francuske.

Relevantni podaci o strukturi demografske bilance u zemljama ove podgrupe pokazuju sljedeće. Udjel prirodnog prirasta u porastu ukupnog broja stanovnika tih zemalja kretao se 2012. u rasponu između 62,0\% (Velika Britanija) i 82,4\% (Francuska). Uzmimo ponovo primjer Francuske kao zemlje s najduljom tradicijom stimulativne populacijske politike. ${ }^{17}$ Porast ukupnog broja stanovnika te godine iznosio je 305.500 , s tim da je prirodni prirast iznosio 251.700 , a pozitivan migracijski saldo 53.000. Prirodni prirast stanovništva bio je prema tome brojčano gotovo pet puta veći od pozitivnog migracijskog salda, a njegov udjel u porastu ukupnog broja stanovnika Francuske bio je također relativno visok i iznosio je $82,4 \%{ }^{18}$

Drugu podgrupu u okviru prve grupe zemalja čine sljedeće četiri zemlje: Irska, Njemačka, Italija i Austrija. U njima je također zabilježen porast ukupnog broja

$\overline{17}$ Vidjeti: Berelson,B., Populaton Policies in Developed Countries, McGraw Hill, New York, 1974; zatim - Glass, D.V, , Population Policies and Movement in Europe, Chapter III, France and Belgium, Augustus McKelly, London 1967. Također, Chesnais, J. C., Les Crépuscule de l'Occident, Démographie et Politique, Edition Robert Lafont, S.A.Paris 1995.

Slovenija je također 2012. imala relativno visok udjel prirodnog prirasta u ukupnom porastu stanovništva, koji je iznosio je 3.300, a prirodni prirast 2.700, tako da je njegov udjel u porastu ukupnog broja stanovnika Slovenije iznosio $81,2 \%$. 
stanovnika, ali su sastavnice toga porasta imale različit predznak. Porast ukupnog broja stanovnika u Njemačkoj i u Italiji bio je rezultat isključivo pozitivnog migracijskog salda, jer je prirodna promjena pokazala prirodno smanjenje, odnosno negativnu stopu prirodnog „prirasta.“

Instruktivan je primjer Irske, koja je jedina zemlja u okviru druge podgrupe zemalja u kojoj je porast ukupnog broja stanovnika u 2012. godini u cijelosti bio uvjetovan prirodnim prirastom stanovništva. Naime, migracijski je saldo pod utjecajem porasle emigracije koja je premašila imigraciju bio u toj godini negativan. Tako je porast ukupnog broja stanovnika Irske, koji je tada iznosio 8.400 stanovnika, bio uvjetovan isključivo prirodnim prirastom, koji je iznosio 43.400. Istovremeno je negativan migracijski saldo iznosio -35.000, pa je djelovao na smanjenje hipotetičkog porasta ukupnog broja stanovnika koji bi (uz ostale iste uvjete) bio ostvaren da je na njega djelovao samo prirodni prirast. Međutim, valja imati na umu činjenicu da je Irska među navedenim zapadnoeuropskim zemljama bila dugotrajno, još od 19. stoljeća, zemlja emigracije, i to prvenstveno prema prekomorskim zemljama (SAD, Kanada, Australija), i da je među zapadnoeuropskim zemljama imala izrazitu diskrepanciju između razine demografskog i ekonomskog razvoja. Konkretno, Irska je imala relativno najveći prirodni prirast stanovništva uz istovremeno relativno nisku razinu ekonomskog razvoja, što je i bio glavni čimbenik njezine visoke emigracije, tj. visokog negativnog migracijskog salda. Totalna stopa fertiliteta u Irskoj još je 1985. godine bila najveća među zapadnoeuropskim zemljama, iznosila je 3,27 djece na jednu ženu u fertilnoj dobi i dugotrajno je determinirala njezin - $\mathrm{u}$ odnosu na ostale navedene zapadnoeuropske zemlje - najveći reprodukcijski potencijal. ${ }^{19}$ Totalna stopa fertiliteta Irske bila je, unatoč iskazanom smanjenju, i u 2012. godini još uvijek među najvišima u zapadnoeuropskim zemljama (iznosila je 2,o1). Valja napomenuti da je nakon 2005. godine ta stopa pokazala porast (u 2005. je iznosila 1,86, a u 2012. godini 2,01). U 2013. godini ona je smanjena na 1,96 i bila je druga po veličini među navedenim zemljama (iza Francuske, u kojoj je iznosila 1,99 djece na jednu ženu u fertilnoj dobi). ${ }^{20}$

U drugu podgrupu u okviru prve grupe navedenih zemalja ulaze, kako smo vidjeli, uz Irsku još i Njemačka i Italija, koje također bilježe porast ukupnog broja stanovnika i već dulje vrijeme pokazuju zanimljivu strukturnu kompoziciju

\footnotetext{
19 U 1960. godini Irska je među navedenim zemljama imala najveću totalnu stopu fertiliteta (koja je iznosila 3,85 djece). Ta je stopa još u 1970. godini Iznosila 4,04, da bi u 1990. pala gotovo na razinu zamjenske reprodukcijske stope, na kojoj se održala i u 2012. godini ( kada je iznosila 2,01 ), i još je uvijek bila među navedenim zemljama jedna od najvećih. Prema, Council of Europe, 2004, Recent demographic developments in Europe, Strasbourg, 2004. 
demografske bilance. Napominjemo da im se između 1.1.2012. i 1.1.2013. godine pridružila i Austrija, koja je dotada pripadala prvoj podgrupi zemalja, jer je, za razliku od Njemačke i Italije, u ranijim godinama zabilježila samo povremeno prirodno smanjenje stanovništva. ${ }^{21} \mathrm{U}$ Njemačkoj i Italiji ukupan broj stanovnika u 2012. je godini porastao isključivo pod utjecajem pozitivnog migracijskog salda zbog visoke imigracije jer su obje zemlje već otprije imale prirodno smanjenje stanovništva (prirodnu depopulaciju). To se ponajprije odnosi na Njemačku, koja je u europskim razmjerima već vrlo rano, i to od 1972. godine, kontinuirano bilježila prirodno smanjenje stanovništva.22 Stoga je ukupan broj stanovnika Njemačke rastao već od početka 1970-ih godina isključivo pod utjecajem relativno visokog pozitivnog migracijskog salda koji je prema kraju 20. stoljeća, a napose u prvom desetljeću 21. stoljeća, pokazao daljnji trend povećanja. Naglašavamo pri tome da je u 2011. godini u okviru EU-27 evidentirano 32,4 milijuna imigranata, što čini 6,5\% njihova ukupnog stanovništva. Oko $80 \%$ bilo ih je locirano u sljedećih pet zemalja: Njemačka 7,1 milijuna, Španjolska 5,7, Velika Britanija 4,4, Italija 4,2 milijuna, Francuska 3,8 milijuna. Njemačka je prema tome, kao zemlja relativno najvećeg ekonomskog razvoja, imala najveću potražnju za radnom snagom i sukladno tome i najveći broj doseljenika (21,9\% njihova ukupnog broja u EU-27 u 2011. godini), a prvo je mjesto zadržala sve do danas. ${ }^{23}$

Pogledajmo još neke podatke za Njemačku za godinu 2012. Između 1.1.2012. i 1.1.2013. godine ukupan broj stanovnika Njemačke porastao je za 195.800, pri čemu je pozitivan migracijski saldo iznosio 391.900, dok je prirodno smanjenje stanovništva iznosilo -196.100 stanovnika. Proizlazi da je migracijski saldo te

$\overline{21}$ Austrija je prirodno smanjenje zabilježila relativno kasno, u 2005. godini i zatim ponovno tek u 2012. i u 2013., da bi u 2014. zabilježila opet prirodni prirast. Stoga nije moguće meritorno zaključiti da li se tu radi o početku dugoročnog trenda negativnog prirodnog „prirasta“ ili samo o privremenoj pojavi. Prirodni prirast je još 2011. godine u Austriji iznosio 1.630, pozitivni migracijski saldo bio je značajno veći, iznosio 37.100, a porast ukupnog broja stanovnika iznosio je 38.800. Tek u 2012. godini Austrija bilježi negativan prirodni "prirast“ u iznosu od - 500.0, uz visok pozitivan migracijski saldo od 44.200. Tako je ukupan porast stanovništva Austrije iznosio u 2012. pod utjecajem pozitivnog migracijskog salda 43.700. (Izvor, Eurostat, newsrelease, op.cit.).

Podaci Council of Europe, op.cit. (1992) i Eurostat pokazuju da je stopa prirodnog smanjenja stanovništva u Njemačkoj (Istočnoj i Zapadnoj) zabilježena već od 1972. godine i sve je do danas (2015. godine) zadržala negativan predznak. Napominjemo da je do 1990. (do pada „berlinskog zida“) statistika prirodnog kretanja za Njemačku dana odvojeno za Istočnu i Zapadnu Njemačku, pri čemu je prva imala višu brojčanu razinu nataliteta i drugih pokazatelja reprodukcije stanovništva. Tako je u 1970. godini opća stopa nataliteta u Istočnoj Njemačkoj iznosila 13,9 promila, a u Zapadnoj Njemačkoj 13,4; stopa totalnog fertiliteta je u prvoj iznosila 2,19, a u drugoj 2,02, (Prema: Council of Europe, op.cit., 1992. i 2004.).

U Njemačkoj, kako smo već naveli, prirodno smanjenje stanovništva datira od 1972. godine, a u Italiji je ono zabilježeno 23 godine kasnije (od 1995.). (Prema: Eurostat - newsrelease, Demography Report, Latest figures on the demographic challanges in the EU, 2010, 2011, 2012.) 
godine kao i ranijih godina bio bitna i jedina determinanta porasta ukupnog broja stanovnika te zemlje. U godini 2012. migracijski je saldo svojim brojem dva puta nadvisio zabilježeni porast ukupnog broja stanovnika Njemačke (koji je u toj godini iznosio 195.800). Sličan je primjer Italije, koja je također u 2012. zabilježila porast ukupnog broja stanovnika unatoč negativnom prirodnom "prirastu." Ali, za razliku od Njemačke, Italija je negativan prirodni "prirast“ zabilježila znatno kasnije od Njemačke počevši tek od 1995. godine. ${ }^{24}$ Ukupan porast stanovništva Italije u 2012. godini bio je kao i kod Njemačke uvjetovan isključivo pozitivnim migracijskim saldom. Relevantni podaci demografske bilance Italije za tu godinu pokazuju da je ukupan broj stanovnika porastao za 291.000, s tim da je negativan prirodni "prirast“ iznosio -78.700 , a pozitivan migracijski saldo čak 369.700, te je bio gotovo 1,3 puta veći od porasta ukupnog broja stanovnika te zemlje.

U današnjoj velikoj seobi naroda, najvećoj poslije Drugoga svjetskog rata, stotine tisuća imigranata iz zemalja Bliskog istoka i sjeverne Afrike svakodnevno stižu u Europu, a većina imigranata ističe da im je krajnja destinacija Njemačka, uz koju se najčešće spominju još Velika Britanija i Švedska, u kojima visok životni standard obećava „bolji život".

Drugu grupu zapadnoeuropskih zemalja, prema formalnom demografskostatističkom kriteriju predznaka promjene ukupnog broja stanovnika, čine $\mathrm{u}$ 2012. godini iz razmatrane grupe one zemlje u kojima je zabilježeno smanjenje ukupnog broja stanovnika. To su Portugal i Španjolska (iz grupe navedenih zapadnoeuropskih zemalja) i Hrvatska (čiju demografsku bilancu uspoređujemo s demografskom bilancom zapadnoeuropskih zemalja).

Valja napomenuti da se Portugalu i Hrvatskoj u smanjenju ukupnog broja stanovnika u razdoblju od 1.1.2012. do 1.1.2013. odnosno u 2012. godini, pridružila i Španjolska, koja - iako je te godine zabilježila smanjenje ukupnog broja stanovnika - nije reprezentativan primjer ni za zemlje sa smanjenjem ukupnog broja stanovnika ni za promjenu strukture demografske bilance zemalja u kojima je tada zabilježena ukupna depopulacija. Naime, dok su za Portugal i Hrvatsku u 2012. godini zabilježeno smanjenje ukupnog broja stanovnika uvjetovale obje agregatne (sumarne) sastavnice demografske bilance (i negativan prirodni „prirast“ i negativan migracijski saldo), u Španjolskoj je smanjenje ukupnog bro-

24 U Italiji je 1995. godine zabilježena po prvi puta stopa prirodnog smanjenja stanovništva (od -0.5 promila), pa je zatim stalno rasla tako da je 2014. godine iznosila $-1,6$ promila. Totalna stopa fertiliteta je još 1970. iznosila 2,43, da bi u 1980. pala na 1,64, a najnižu brojčanu vrijednost je zabilježila 1995. godine, kada je iznosila svega 1,21. Nakon toga je polagano rasla i u 2013 godini je iznosila 1,39. (Ibidem, prethodna bilješka; također, Lanzieri,G., Towards a „baby recession“ in Europe? Differential fertility trends during the economic crisis, Eurostat, Statistics in focus 13/2013. 
ja stanovnika te godine uvjetovao samo negativni migracijski saldo, što ranijih godina nije bio slučaj. Španjolska je naime dugo bila zemlja imigracije (primarno za zemlje Latinske Amerike), a osim toga u razdoblju između 1960. i 2012. u većini godina bilježila je prirodni prirast stanovništva. ${ }^{25}$

U tom kontekstu važna je činjenica da je nastalo smanjenje ukupnog broja stanovnika u 2012. godini u tri navedene zemlje bilo je izraz različitog smjera prirodne i migracijske promjene, preciznije rečeno različitog predznaka i udjela prirodne i migracijske promjene u smanjenju ukupnog broja stanovnika. Kod Portugala i Hrvatske tada je zabilježeno smanjenje ukupnog broja stanovnika bilo izraz, kako smo već naglasili, smanjenja obiju agregatnih sastavnica demografske bilance, $\mathrm{t} j$. i negativnog prirodnog "prirasta“ i negativnog migracijskog salda, a kod Španjolske samo negativnog migracijskoga salda (jer je Španjolska imala pozitivnu stopu prirodne promjene).

Prema tome, $u$ navedenoj grupi zemalja koje su zabilježile smanjenje ukupnog broja stanovnika demografski je reprezentativan, uz Hrvatsku, i primjer Portugala. Za prirodno kretanje stanovništva Portugala karakteristično je da je između 1960. i 2004. godine obilježeno prirodnim prirastom stanovništva. Zatim se između 2004. i 2009. godine prirodni prirast postupno smanjivao, da bi u svim godinama između 2007. i 2014. došlo do prirodnog smanjenja stanovništva. Sukladno tome, totalna je stopa fertiliteta, počevši od 1985. godine nadalje, u Portugalu pala ispod brojčane razine zamjenske stope, tako da je npr. u 2008. bila izrazito niska, iznosila je svega 1,37 djece po jednoj ženi u fertilnoj dobi.26 Dakle, ukupan rezultat demografske bilance Portugala u 2012. godini pokazao je smanjenje ukupnog broja stanovnika koji su determinirale obje agregatne sastavnice demografske bilance, i prirodna i migracijska sastavnica, koje su imale negativan predznak.27 Tako je te godine ukupan broj stanovnika Portugala smanjen za - 55.100, pri čemu je prirodno smanjenje stanovništva iznosilo -17.800, a ne-

$\overline{25}$ Španjolska je u 1960. godini imala prirodni prirast, a bila je istovremeno i zemlja imigracije. Još u 1985. godini totalna stopa fertiliteta bila je na razini zamjenske stope $(2,1)$, a stopa prirodnog prirasta stanovništva iznosila je 3,7 promila i ostala je pozitivna sve do 2012. godine. U smanjenju ukupnog broja stanovnika Španjolske u iznosu od -162.400 nastalom u 2012. godini, prirodni je prirast stanovništva sudjelovao s 48.500, a negativni saldo migracije iznosio je - 162.400. (Ibidem, prethodna bilješka).

26 U Portugalu je ukupan broj stanovnika do godine 2009. rastao, a između 2010. i 2015. smanjen je na 10.573 tisuća. Stopa prirodnog prirasta još je 2006. Iznosila 0,3 promila, 2007. je pala na $-0,1$ promila s tim da je do 2014. godine stalno bila negativna. Između 2001. I 2014. smanjena je sa $-0,5$ promila na $-2,2$ promila. (Povećala se za oko četiri i pol puta). Totalna stopa fertiliteta u Portugalu je tek u 1990. godini smanjena ispod razine zamjene od 2,1 i iznosila je 1,56, u 2011. godini je dalje smanjena na 1,35., a u 2013. godini na 1,21 djece na jednu ženu u fertilnoj dobi. (Eurostat, serija Total fertility rates).

Prema: EU Employment and Social Situation, Quarterly Review, March 2013; te Eurostat newsletter, November 2013., op.cit. 
gativni migracijski saldo -37.300. Prema tome, dominantna odrednica smanjenja ukupnog broja stanovnika Portugala bio je negativni migracijski saldo, koji je pridonio ukupnom smanjenju njegova stanovništva s udjelom od $67,7 \%$.

Primjer Hrvatske kao zemlje koja je u 2012. godini zabilježila smanjenje ukupnog broja stanovnika umnogome je sadržajno specifičan i statistički reprezentativan primjer zemlje koja dugoročno, kontinuirano i stabilno, već četvrt stoljeća, između 1990. i 2015. godine, bilježi smanjivanje ukupnog broja stanovnika, dakle proživljava proces ukupne depopulacije. Osim toga primjer Hrvatske među navedenim zapadnoeuropskim zemljama, a napose $\mathrm{u}$ drugoj navedenoj podgrupi tih zemalja, analitički je relevantan i sadržajno specifičan s obzirom na četiri bitna specifična obilježja prirodne i migracijske dinamike sastavnica demografske bilance. Prvo specifično demografsko i dinamičko obilježje Hrvatske odnosi se na duljinu razdoblja u kojem je zabilježeno smanjenje ukupnog broja stanovnika i prirodno smanjenje stanovništva. Drugo se odnosi na signifikantno nižu brojčanu razinu nataliteta/fertiliteta Hrvatske u odnosu na većinu ostalih zemalja iz podgrupe razmatranih zemalja. Treće specifično demografsko obilježje odnosi se na intenzitet povećavanja, preciznije rečeno na akceleraciju povećavanja negativnog prirodnog „prirasta“ kao negativne prirodne sastavnice demografske bilance, koje se događa istovremeno s povećavanjem negativne migracijske sastavnice (emigracije) u njezinoj demografskoj bilanci. Četvrto specifično obilježje odnosi se na znatno nižu (u odnosu na druge razmatrane zapadnoeuropske zemlje) razinu ekonomskog razvoja Hrvatske.

U području ukupnog i prirodnog kretanja stanovništva za Hrvatsku je karakteristično da je u prvom podrazdoblju poslije Drugog svjetskog rata (1955. - 1990.) ukupno stanovništvo pokazalo porast, koji je postajao sve sporiji. Odnosno, Hrvatska je tada imala pozitivnu ukupnu i prirodnu promjenu (prirodni prirast), ali uz naglašeno smanjivanje stope ukupnog porasta i stope prirodnog prirasta stanovništva nakon 1955. godine s tendencijom prema nultom prirodnom prirastu. ${ }^{28}$ Valja naglasiti da je totalna stopa fertiliteta u Hrvatskoj bila već u 1970. godini vrlo niska, najniža među razmatranim zapadnoeuropskim zemljama (iznosila je 1,83). ${ }^{29}$ Zatim je iz godine u godinu permanentno opadala, tako da je u 1990. iznosila 1,67, a u 2015. godini (procjena) 1,41 djece na jednu ženu u fertilnoj dobi. Hrvatska je dakle tijekom navedenoga razdoblja zabilježila ubrzano smanjivanje već i tako niske razine nataliteta/fertiliteta i ostalih poka-

\footnotetext{
28 Prema: Wertheimer-Baletić, Stanovništvo SR Hrvatske - Studije, Školska knjiga, 1971, Zagreb

29 Istu brojčanu vrijednost totalne stope fertiliteta $(1,83)$ zabilježila je u 1970. godini i Finska. Za njom slijedi Švicarska sa stopom 1,92, Danska sa stopom od 1,95 te Luxemburg $(1,97)$. Vidjeti: Council of Europe, Recent demographic developments in Europe 2004, Strasbourg
} 
zatelja reprodukcije stanovništva, kojem je nesumnjivo znatno pridonio rastući negativni migracijski saldo.

U drugom podrazdoblju, između 1990. i 2015., taj se negativan trend u Hrvatskoj intenzivirao, što je povezano, između ostaloga, i s ratnim gubicima stanovništva u Domovinskom ratu kao razdoblju koje redovito ima posljedicu tzv. depresirani natalitet. Bitno je podvući i specifičnost Hrvatske da su u tom drugom podrazdoblju negativni prirodni ",prirast“ i negativni migracijski saldo zajednički pridonijeli smanjivanju ukupnog broja stanovnika Hrvatske. Tada je Hrvatska među razmatranim zapadnoeuropskim zemljama bila (uz Portugal) jedina zemlja koja je imala ukupnu depopulaciju, odnosno smanjivanje ukupnog broja stanovnika, koju su uvjetovale obje agregatne sastavnice demografske bilance, kako prirodna depopulacija tako i migracijska depopulacija.

Ilustracije radi, navodimo da je između 1.1.2012. i 1.1.2013. ukupan broj stanovnika Hrvatske smanjen s 4.276 tisuća na 4.262 tisuće ili za ukupno 13.800 stanovnika. Smanjenju ukupnog broja stanovnika te je godine jače pridonio negativni prirodni "prirast", koji je iznosio -9.9 oo ili 71,7\% od smanjenja ukupnog broja stanovnika, dok je negativni migracijski saldo bio znatno manji, iznosio je - 3.900 i činio je $26,3 \%$ od smanjenja ukupnog broja stanovnika. ${ }^{30}$

Evidentno je prema tome da su obje navedene sastavnice demografske bilance Hrvatske imale u drugom podrazdoblju (1990. - 2015.) negativan predznak, što objektivno, uz iste ostale čimbenike, ističe sadašnje krajnje nepovoljne demografske prilike s brojnim negativnim implikacijama $u$ svim područjima društveno-ekonomskog života i ukupnog razvoja.

\section{ZAKLJUČAK}

Budući da se često naglašava da su demografski procesi i promjene u Hrvatskoj tijekom posljednjih pedeset godina (1955. - 2015.) identični s procesima koji se odvijaju u zapadnoeuropskim zemljama, iz prezentiranog razmatranja može se zaključiti o kojim se demografskim procesima radi (agregatnim ili parcijalnim) i u kojem razdoblju, zatim koji je u navedenom polustoljetnom razdoblju ili u pojedinim njegovim podrazdobljima (srednjoročnim ili kratkoročnim) bio smjer promjene tih procesa (porast, smanjenje), koje su karakteristične promjene prema smjeru dinamike tih procesa nastale $\mathrm{u}$ demografskoj bilanci i u njezinim sastavnicama (prirodnim i migracijskim), kakav je bio intenzitet promjene tih procesa $\mathrm{i}$ pod utjecajem kojih sastavnica demografske bilance u razmatranim zapadnoeuropskim zemljama u usporedbi s odgovarajućim promjenama u Hrvatskoj.

Izvor podataka, Eurostat, november 2013, vidjeti bilješku br. 3 (u ovom tekstu). 
Ta usporedba pokazuje $\mathrm{u}$ navedenom razdoblju značajne razlike između demografskih procesa i promjena u navedenim zapadnoeuropskim zemljama, s jedne strane, i u Hrvatskoj, s druge. Usporedba se odnosi na jednogodišnje razdoblje (1.1.2012. - 1.1.2013.). To se razdoblje, prema promjenama demografske bilance i njezinih sastavnica, može na temelju uvida $u$ relevantne dugoročne vremenske serije adekvatnih demografsko-statističkih podataka i na temelju izraženih demografskih tendencija, procesa i promjena smatrati reprezentationim za dulje razdoblje, konkretno za razdoblje 1990. - 2015. godine.

U ovom smo radu nastojali odgovoriti na gornja pitanja i ukazati na razlike koje se pojavljuju između razmatranih zapadnoeuropskih zemalja i Hrvatske $\mathrm{u}$ temeljnim agregatnim demografskim procesima i promjenama sastavnica demografske bilance. Naglasak je na smjeru i intenzitetu promjene pojedinih determinanti procesa ukupne depopulacije, prirodne depopulacije i strukture demografske bilance s obzirom na različite odnose i pondere njezinih pojedinih prirodnih i migracijskih sastavnica. Pri tome je u zapadnoeuropskim zemljama u odnosu na Hrvatsku izrazito dominantan utjecaj migracijskih sastavnica, napose utjecaj imigracije, na ukupan porast njihova stanovništva tijekom posljednja dva i pol desetljeća.

Analitička obrada raspoloživih podataka koji pokazuju usporednu tendenciju dinamike i smjera agregatnih i parcijalnih demografskih procesa u razmatranim zapadnoeuropskim zemljama i u Hrvatskoj pokazala je sljedeće značajke.

Prva značajka odnosi se na temeljni agregatni demografski proces koji u sebi integrira promjene sastavnica demografske bilance (prirodnih i migracijskih). To je proces promjene ukupnog broja stanovnika u navedenom razdoblju. Pokazuje se da 16 od 18 razmatranih zapadnoeuropskih zemalja bilježi prosječnu godišnju stopu porasta ukupnog broja stanovnika te da ona u ukupnom razdoblju 1955. - 2015. ima prosječnu godišnju tendenciju smanjenja. To je smanjivanje $u$ pojedinim godinama variralo od zemlje do zemlje, $u$ jednoj je bilo jače, $u$ drugoj slabije, ovisno o specifičnim demografskim, društveno-ekonomskim, političkim i drugim uvjetima i čimbenicima. Takva tendencija koja pokazuje prosječni godišnji trend smanjivanja stope porasta ukupnog stanovništva izražena je i u Hrvatskoj, ali samo u prvom navedenom podrazdoblju, 1955. - 1990. godine. $\mathrm{U}$ tom se dakle podrazdoblju smjer promjene prosječne godišnje stope porasta ukupnog stanovništva Hrvatske podudara sa smjerom promjene te stope u razmatranim zapadnoeuropskim zemljama. Znači da u podrazdoblju 1955. - 1990. godine dinamiku stanovništva u Hrvatskoj, kao i u navedenim zapadnoeuropskim zemljama, obilježava prosječna godišnja stopa porasta ukupnog broja stanovnika. Prema tome, u tom podrazdoblju u Hrvatskoj, kao i u ostalim nave- 
denim zapadnoeuropskim zemljama, još uvijek postoji proširena reprodukcija stanovništva s padajućom tendencijom.

Međutim, u drugom podrazdoblju, 1990. - 2015., za razliku od razmatranih zapadnoeuropskih zemalja, koje još uvijek bilježe stopu porasta ukupnog broja stanovnika, u Hrvatskoj dolazi do radikalne promjene. Za razliku od navedenih zapadnoeuropskih zemalja, u Hrvatskoj već 25 godina traje proces smanjivanja ukupnog broja stanovnika, pa stopa promjene ukupnog broja stanovnika ima negativan predznak. Hrvatska je prema tome među razmatranim zapadnoeuropskim zemljama jedina zemlja u kojoj se ukupan broj stanovnika između 1990. i 2015. godine kontinuirano smanjivao. Slijedi da je u Hrvatskoj u navedenom razdoblju u tijeku proces ukupne depopulacije, dok je $u$ razmatranim zapadnoeuropskim zemljama (kojih su većina članice EU-28) i dalje u tijeku proces porasta ukupnog broja stanovnika. Vidjeli smo da većina tih zemalja kontinuirano, $\mathrm{u}$ oba navedena podrazdoblja, ima godišnji porast ukupnog broja stanovnika. To je prva i temeljna razlika između Hrvatske i navedenih zapadnoeuropskih zemalja koju u podrazdoblju 1990. - 2015. godine sadrži iskazani diferencijalni agregatni demografski proces promjene ukupnog broja stanovnika.

Druga značajka, odnosno razlika između demografskih procesa u razmatranim zapadnoeuropskim zemljama i u Hrvatskoj, obuhvaća razliku sadržanu u strukturi demografske bilance i njezinim sastavnicama na strani aktive i pasive. Iz prethodnih razmatranja proizlazi da strukturu demografske bilance $\mathrm{u}$ zapadnoeuropskim zemljama obilježava pozitivna prirodna promjena, $\mathrm{tj}$. prirodni prirast stanovništva i pozitivni migracijski saldo, a istovremeno strukturu demografske bilance u Hrvatskoj (napose u podrazdoblju 1990. - 2015. godine) obilježava prirodno smanjenje stanovništva, prirodna depopulacija i negativni migracijski saldo (migracijska depopulacija). Rezultantu takve diferencijalne strukture demografske bilance i njezinih sastavnica za navedene zapadnoeuropske zemlje obilježava porast ukupnog broja stanovnika, dok rezultantu demografske bilance i njenih sastavnica u Hrvatskoj obilježava smanjenje ukupnog broja stanovnika.

Treća značajka odnosi se na demografske tendencije nastale u strukturnim promjenama između procesa starenja stanovništva u zapadnoeuropskim zemljama i u Hrvatskoj. Činjenica je da je proces starenja univerzalni proces koji se odvija kako u zapadnoeuropskim zemljama tako i u Hrvatskoj. Taj se proces izražava kroz promjene $u$ dobnoj strukturi stanovništva koje rezultiraju procesom starenja i u zapadnoeuropskim zemljama i u Hrvatskoj, koje pokazuju povećanje broja i udjela starog stanovništva (65 i više godina) u ukupnom broju stanovnika. Smjer tih promjena u obje uspoređivane grupe zemalja identičan je s 
tom razlikom što je u navedenim zapadnoeuropskim zemljama dobna struktura povoljnija nego u Hrvatskoj. Razlog tome jest primarno činjenica da je struktura demografske bilance prema njenim sastavnicama povoljnija u prvima u odnosu na Hrvatsku. Naime, većina navedenih zapadnoeuropskih zemalja ima, kako smo ranije pokazali, pozitivnu prirodnu promjenu (prirodni prirast) uz istovremeni pozitivni saldo migracije, što, uz ostale iste uvjete, pogoduje pomlađivanju dobne strukture ne samo ukupnog već i radnosposobnog stanovništva, odnosno radnog kontingenta, koji je demografski okvir za formiranje radne snage. Naime, prirodni prirast stanovništva i pozitivni migracijski saldo koji obilježavaju demografsku bilancu razmatranih zapadnoeuropskih zemalja ublažavaju demografske posljedice ne samo starenja ukupnog stanovništva već i starenja radnog kontingenta. Time se u navedenim zapadnoeuropskim zemljama smanjuje intergeneracijski demografski disbalans, dok se istovremeno u Hrvatskoj taj disbalans povećava, jer negativan prirodni "prirast“, uz ostale iste čimbenike, djeluje na daljnje smanjivanje broja i udjela mladih u ukupnom stanovništvu te broja i udjela mlađeg dijela radnog kontingenta u ukupnom radnom kontingentu. Povećanje demografskog intergeneracijskog disbalansa u Hrvatskoj ubrzavaju promjene $\mathrm{u}$ dobnoj strukturi stanovništva koje, kako smo napomenuli, uz ostalo, obilježava ne samo opadanje broja i udjela mladog stanovništva $(0-14$ godina) već i broja i udjela mlađeg dijela radnog kontingenta (15 - 34 godine).

Četvrta značajka, odnosno razlika koja obilježava razlike u demografskim procesima između zapadnoeuropskih zemalja i Hrvatske relevantne za sadašnji i budući razvoj njihova stanovništva odnosi se na populacijsku politiku, odnosno na obiteljsku politiku. Činjenica je da većina navedenih zapadnoeuropskih zemalja članica EU-28 nije samo ekonomski znatno razvijenija već i dulje vrijeme provodi određenu širu ili užu, eksplicitnu ili implicitnu obiteljsku, odnosno populacijsku politiku. Skup mjera i akcija te politike nesumnjivo je u navedenim zemljama djelovao na sadašnju relativno višu razinu komponenti prirodnog kretanja stanovništva, napose na višu razinu nataliteta $u$ odnosu na Hrvatsku. Valja naime naglasiti da Hrvatska u razdoblju poslije Drugog svjetskog rata, dakle do 1990. godine, nije imala - kao ni ostale republike u okviru bivše socijalističke Jugoslavije - nikakvu populacijsku politiku. Istovremeno su susjedne bivše socijalističke zemlje, kako je poznato, provodile eksplicitnu pronatalitetnu populacijsku politiku i, sukladno tome, imale su u odnosu na Hrvatsku signifikantno višu razinu nataliteta/fertiliteta i pokazatelja reprodukcije stanovništva.

Konačno možemo zaključiti da je sadašnja demografska slika Hrvatske ukupno i strukturno, za sadašnjost i budućnost, izrazito nepovoljna i u uvjetima 
ekonomske krize koja traje nema ni izgleda da bi se uskoro mogla radikalno popraviti. Pogoršava je nova znatna emigracija mladih obrazovanih ljudi u inozemstvo, napose u zemlje EU. Analitička struktura demografske bilance Hrvatske u usporedbi s demografskom bilancom u razmatranim zapadnoeuropskim zemljama članicama EU-28 pokazala je da se demografski procesi i demografska bilanca Hrvatske $\mathrm{u}$ odnosu na navedene visokorazvijene europske zemlje razlikuju ne samo prema smjeru promjene agregatnih demografskih procesa već napose u području strukture demografske bilance prema njezinim strukturnim sastavnicama, prema iskazanom smjeru promjene sastavnica te bilance, njihova kvantitativnog međuodnosa i, konačno, razlikuju se u krajnjem rezultatu demografskih promjena u tim zemljama i u Hrvatskoj napose u razdoblju posljednjih dvadeset i pet godina. Sumarna značajka koja određuje razliku demografske perspektive između većine navedenih zapadnoeuropskih zemalja i Hrvatske sastoji se $\mathrm{u}$ činjenici da prve imaju u uvjetima visoke razine ekonomskog razvoja prirodni prirast stanovništva i uz to visok pozitivan migracijski saldo, a Hrvatska, u uvjetima znatno niže razine ekonomske razvijenosti, ima u sadašnjim ekonomskim prilikama upravo suprotne bitne demografske karakteristike - prirodno smanjenje stanovništva s tendencijom pogoršanja i negativni migracijski saldo s tendencijom povećanja. 


\section{Literatura}

BERELSON, B., Population policies in developed countries, McGraw Hill, New York, 1974

CHESNAIS, J.C., Les Crepuscile de l'Occident, Démographie et Politique, Edition Robert Lafont, S.A. Paris 1995

Council of Europe, Recent demographic developments in Europe, 1992 i 2004, Strasbourg

Eurostat newsrelease, Demographic Report, Latest figures on the demographic challenges in the EU, 2010, 2011, 2012

Eurostat Demography Report 2013.

Eurostat newsrelease, 173/2013 - 20 November 2o13, European demography, EU-28 population 505,7 milion at 1 January 2013.

EU Employment and Social Situation, Quarterly Review, Special Supplement on Demographic Trends, March 2013.

GLASS, D, V., Population Policies and Movement in Europe, Chapter II, France and Belgium, Augustus McKelly, London 1967

HÖEM, B. (2000), Entry into Matherhood in Sweden: influence of economic factors on the rise and fall in fertility, 1986-1997, Demographic Research 2 (4)

HÖEM, J.M. (1986), The impact of education on modern fertility, European Journal of Population, no. 2

HÖEM, J.M. (1993), Public policy as the fact in fertility: Effect on the Pace of Childbearing in Sweden in 1980 's, Acta Sociologica, 3,4

LANZIERI, G. Towards a „baby recession“ in Europe? Differential fertility trends during the economic crises, Eurostat, Statistics in Focus 13/ 2013

UN, Department of Economic and Social Affairs, World Population Prospects, 2015 Revision, Vol. I, New York

VAN de KAA, D., (1987) Europe 's Second Demographic Transition, Population Bulletin, Vol. 42, No. 1, Washington D.C

WERTHEIMER-BALETIĆ, A. (1971), Stanovništvo SR Hrvatske - Studije, Školska knjiga, Zagreb

WERTHEIMER_BALETIĆ, A., Demografski okviri ponude radne snage u Jugoslaviji, Ekonomist br. 1-2/ 1974

WERTHEIMER-BALETIĆ, A., Ekonomski aktivno stanovništvo SR Hrvatske - stanje i tendencije, Ekonomski pregled br. 11-12/1983 


\section{Summary}

\section{Demographic Processes in Croatia and Western European Countries - Differences, Similarities and Specificities}

In this paper, main demographic processes and demographic balance in Croatia and in 18 Western European countries, mostly EU members, have been compared. The conclusion was that demographic processes in Croatia differed from the ones in the said Western European countries during previous two and a half decades. Among the analysed countries, Croatia was the only one with a permanent yearly decrease in the total population number during previous two and a half decades, while the analysed Western European countries have synchronously recorded a constant increase in the total population number. The analysis of the structure of the demographic balance of Croatia and the said countries shows - according to its basic components - a significantly different structure. In Croatia, above all, both summary components of the demographic balance are negative, so that the decrease in the total population number has been synchronously conditioned by natural population decrease and negative migration balance. However, this structure is different in the analysed Western European countries. It is evident that the increase in the total population number in these countries has been synchronously conditioned by positive migration balance and positive natural change, i.e. natural population increase. These aggregate and structural characteristics of the final result of demographic balance and its structures in Croatia and in the said countries have had an entirely different influence on future demographic movements and changes of the structures in Croatia and in the said countries: in Croatia, projections indicate that unfavourable demographic changes will become intensified in the future; while in Western European countries, they foresee a further increase in the total population number, in particular population capable for work, which is related to future positive structural demographic changes.

Keywords: demographic balance; components of the demographic balance; components of the natural change; components of the migration change; total depopulation; natural depopulation. 